\title{
PENERAPAN MILIEU TEACHING DALAMI MENINGKATKAN KEMAMPUAN BAHASA EKSPRESIF PADA ANAK YANG MENGALAMI KETERLAMBATAN BAHASA
}

\author{
Danella Merdiasi \\ Universitas Tarumanagara \\ Jl. Letjen S. Parman No 1, Grogol, Jakarta Barat \\ danellamerdiasi@gmail.com, 085249236080 \\ Sri Tiatri \\ Universitas Tarumanagara \\ Jl Letjen S. Parman No 1, Grogol, Jakarta Barat \\ srit@fpsi.untar.ac.id, 085885025069 \\ Fransisca I. R. Dewi \\ Universitas Tarumanagara \\ J1 Letjen S. Parman No 1, Grogol, Jakarta Barat \\ fransiscar@fpsi.untar.ac.id, 082123132073
}

\begin{abstract}
This study aims to determine the implementation of milieu teaching in improving the ability of expressive language in children who experience language delays. One of the early language interventions used was milieu teaching. Milieu teaching is a naturalistic intervention approach that uses conversational-based strategies to improve language and communication skills in children. Participants in this study amounted to 1 child of a 4-year-old male who experienced language delays and is currently studying in Kindergarten. This research is an experimental research with research design that is single subject design. In this research design, there will be three sessions, namely baseline 1, intervention phase, and baseline 2 stages in order to find out whether or not there is an increase in each session. Data analysis techniques used are visual data analysis techniques based on the results of observation data. Based on the calculation, it is known that there is an improvement of expressive language in children who experience language delay through the application of milieu teaching.
\end{abstract}

Keywords: Expressive Language, Language Delay, Milieu Teaching Intervention

\section{PENDAHULUAN}

\section{A. Latar Belakang}

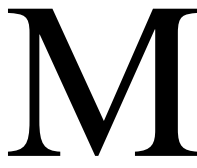

asa kanak-kanak merupakan masa terjadinya perubahan pesat dalam semua aspek perkembangan yang meliputi perkembangan motorik, perkembangan kognisi, perkembangan sosial dan perkembangan bahasa (Slavin, 2009). Masa kanak-kanak awal merupakan periode perkembangan yang terjadi mulai usia 2 tahun hingga sekitar usia 5 atau 6 tahun. Masa ini juga disebut juga masa pra sekolah (Santrock, 2007). 
Salah satu perkembangan yang penting pada masa kanak-kanak yaitu perkembangan bahasa. Menurut Newman (dikutip dalam Friend, 2011), Bahasa merupakan sistem simbol terstruktur yang digunakan untuk menyampaikan gagasan dan informasi secara lisan, tertulis atau isyarat. Bahasa meliputi pemahaman, pengolahan, dan produksi komunikasi. Bagi anak, bahasa adalah keterampilan yang paling penting karena anak membutuhkan keterampilan bahasa untuk dapat berhasil di sekolah dan dalam kehidupan sehari-hari (Morrison, 2008).

Melalui bahasa anak dapat melakukan interaksi sosial dan sebagai persiapan kemampuan membaca dan menulis (Lonigan, Burgess \& Anthony dikutip dalam Papalia, Olds, \& Feldman, 2009). Bahasa juga memungkinkan anak untuk mempelajari keterampilan baru dan selanjutnya mengembangkan kemampuan bahasa mereka. Sebagai contoh, komunikasi yang efektif memungkinkan anak-anak untuk terlibat dalam interaksi sosial, dimana mereka meningkatkan keterampilan verbal, merespon dan pemecahan masalah (Stock \& Fisher, 2006).

Mash dan Wolfe (2014) menyatakan setiap tahapan perkembangan memiliki potensi terjadinya gangguan atau keterlambatan, tergantung pada tugas perkembangan masing-masing usia. Gangguan bahasa adalah salah satu penyebab terhambatnya tumbuh kembang anak. Gangguan bicara dan bahasa yang seringkali dialami anak yaitu dalam hal keterlambatan bahasa. Secara umum, seorang anak dianggap memiliki keterlambatan bahasa apabila perkembangan bahasanya tidak sesuai dengan tahapan perkembangan anak seumurannya. Seorang anak dengan keterlambatan bahasa biasanya memiliki perkembangan bahasa di bawah usia kronologisnya, kemampuan anak yang mengalami keterlambatan diperoleh dalam urutan yang normal, hanya saja pada tingkat yang lebih lambat dari biasanya (Heward, 2012).

Keterlambatan bahasa yang seringkali dikeluhkan oleh orangtua yaitu anaknya belum mampu berbicara ataupun tidak mengerti mengerti maksud bahasa yang disampaikan oleh orangtua. Keterlambatan bahasa tersebut dapat berkaitan dengan keterlambatan bahasa reseptif dan ekspresif. Bahasa reseptif adalah penerimaan dan pemahaman atas bahasa sedangkan bahasa ekspesif merupakan kemampuan memproduksi bahasa (Stock \& Fisher, 2006).

Keterlambatan dalam bahasa ekspresif yaitu dimana anak mengalami kesulitan mengekspresikan dirinya dalam berbicara. Anak tampak ingin berkomunikasi, namun mengalami kesulitan yang luar biasa untuk menemukan kata-kata yang tepat. Di usia 4 tahun, anak hanya mampu berbicara dengan kalimat pendek. Kata-kata yang dikuasai terlupakan dan penggunaan struktur tata bahasa sangat di bawah tingkat usianya (Kring, Johnson, Davidson, \& Neale, 2009). Keterlambatan bahasa ekspresif dapat menimbulkan masalah seperti kesulitan dalam literasi awal, prestasi sekolah, perilaku dan hubungan dengan teman dan keluarga. Anak-anak dengan keterlambatan juga mungkin dapat menimbulkan resiko untuk mendapatkan ejekan dari orang lain (Stock \& Fisher, 2006). 
Melihat sedemikian besarnya dampak yang ditimbulkan akibat gangguan berbahasa pada kehidupan anak yang mengalami keterlambatan bahasa ekspresif maka sangatlah penting untuk mengoptimalkan proses perkembangan bahasa. Salah satu metode intervensi yang cukup banyak digunakan untuk meningkatkan kemampuan bahasa ekspresif yaitu intervensi naturalistik yang juga dikenal dengan nama milieu teaching. Kaiser, Hancock dan Nietfeld (2010) menyatakan bahwa milieu teaching merupakan pendekatan intervensi naturalistik yang menggunakan strategi berbasis percakapan untuk meningkatkan keterampilan bahasa dan komunikasi pada anak. Terdapat empat strategi dari milieu teaching yang digunakan untuk mendukung keterlibatan anak dan mengajukan pertanyaan mengenai benda dan aktivitas. Keempat strategi tersebut yaitu model, mand-model, time delay, dan incidental teaching. Pada penerapannya, millieu teaching dapat dilakukan pada lingkungan yang menarik minat anak dan meningkatkan kemungkinan interaksi komunikatif terjadi yang digunakan untuk tujuan pembelajaran seperti pada anak-anak usia dini dapat dilakukan di ruang bermain.

Robert dan Kaiser (2012) juga menjelaskan bahwa metode milieu teaching memiliki dampak positif yang kuat pada kemampuan bahasa reseptif dan ekspresif anak dengan gangguan bahasa, termasuk anak-anak dengan disabilitas intelektual. Menurut Kaiser dan Trent (2007) mengungkapkan bahwa milieu teaching sebagai pendekatan intervensi yang juga ditujukan untuk meningkatkan pengasuhan, interaksi sosial dan komunikatif anak di lingkungan yang alami. Pada penelitian yang dilakukan oleh Kaiser, Scherer, Frey, dan Roberts (2017) intervensi naturalistik yang dikenal dengan milieu teaching menunjukan bahwa metode tersebut efektif dalam meningkatkan bahasa ekspresif pada anak yang mengalami significant language impairment dan meningkatkan produksi fonologis pada anak pra sekolah yang mengalami keterlambatan bahasa. Akan tetapi, penelitian mengenai penerapan milieu teaching di Indonesia masih terbatas.

\section{B. Rumusan Masalah}

Rumusan masalah dalam penelitian ini adalah "apakah penerapan intervensi milieu teaching dapat meningkatkan kemampuan bahasa ekspresif pada anak yang memiliki keterlambatan bahasa?"

\section{METODE PENELITIAN}

Subyek dalam penelitian ini berjumlah 1 subyek $(\mathrm{N}=1)$ merupakan seorang anak berjenis kelamin laki-laki berusia 4 tahun, berinisial ED. ED mengalami kesulitan dalam berkomunikasi dengan orang-orang di sekitarnya seperti dengan orangtua, guru maupun teman-temannya di sekolah. Kesulitan yang dialami ED yaitu saat mengatakan sesuatu keinginan kepada orang di sekitarnya, ED lebih sering hanya menggunakan satu ataupun kombinasi dua kata saat sedang berbicara dan diberikan pertanyaan. ED lebih banyak memberikan jawaban dengan menggunakan bahasa tubuh seperti mengangguk 
atau menggelengkan kepala. Hal tersebut membuat guru maupun temannya kesulitan untuk memahami hal yang dikatakan atau diinginkan ED.

Penelitian ini menggunakan metode eksperimen dengan single subject design dan target behavior dalam penelitian ini yaitu kemampuan ED dalam memproduksi kombinasi tiga kata (saya mau nama aktivitas/benda yang diinginkan). Penentuan target behavior berdasarkan pada hasil DDST (Denver Development Screening Test), observasi dan wawancara yang telah dilakukan. Single subject design merupakan metode penelitian yang digunakan untuk mengevaluasi efektivitas intervensi dengan individu (Gast, 2010). Dalam penggunaan metode penelitian ini biasanya, partisipan berjumlah sedikit yang diteliti yaitu hanya merupakan sampel penelitian dan mengalami suatu variabel yang dimanipulasi. Pada penelitian ini juga tidak adanya kelompok kontrol yang berfungsi sebagai pembanding subjek tunggal.

Desain penelitian yang digunakan adalah desain reversal (desain pengulangan) yaitu baseline 1 (A1) - intervensi (B) - baseline 2 (A2). Tahap baseline 1 merupakan tahap saat target behavior pada kondisi awal atau sebelum intervensi dilakukan, tahap intervensi merupakan kondisi target behavior selama intervensi berlangsung dan tahap baseline 2 merupakan tahap setelah target behavior diberikan intervensi. Desain ini dilakukan sebagai kontrol untuk fase intervensi sehingga memungkinkan menarik kesimpulan adanya hubungan fungsional yang lebih kuat antara variabel bebas dan variabel terikat. Penelitian ini menggunakan pencatatan kejadian (event recording). Jenis teknik pencatatan data menggunakan behavior tallying yaitu melakukan pencatatan terhadap target perilaku bentuk frekuensi dan kemudian ditally. Pengolahan data dilakukan melalui perhitungan statistik deskriptif dengan analisis data yaitu menggunakan analisis data visual berdasarkan hasil observasi.

Dalam penelitian eksperimen ini, kemampuan ED dalam memproduksi bahasa sebelum diberikan intervensi akan diamati selama 3 sesi (baseline) dan lama setiap sesi yaitu 20 menit. Kemudian program khusus akan dimulai yaitu pelaksanaan milieu teaching yang dilakukan selama 8 sesi yaitu setiap sesi selama 30 menit. Adapun dalam program ini kemampuan anak dalam memproduksi bahasa akan diamati (intervensi). Setelah program milieu teaching selesai diberikan, anak akan diamati kembali pada setting yang sama (baseline 2) selama 3 sesi dan lama setiap sesi yaitu 20 menit. Apabila kemampuan ED dalam memproduksi kombinasi tiga kata saat menginginkan sesuatu mengalami peningkatan pada program ini, implikasinya ialah bahwa penerapan strategi milieu teaching dapat meningkatkan kemampuan dalam memproduksi bahasa (bahasa ekspresif).

\section{HASIL DAN PEMBAHASAN}

Berdasarkan pengukuran dengan menggunakan DDST diperoleh gambaran mengenai kemampuan bahasa yang menunjukkan bahwa kemampuan ED setara dengan anak usia 24 bulan yaitu ED mampu menoleh pada suara, mengucapkan papa mama, 
meniru suara pembicaraan, menyebutkan tiga kata lainnya, mengenal warna, dan menyebutkan 4 nama kegiatan. ED juga mampu mengikuti perintah dan menyebutkan nama anggota tubuh. Sedangkan kemampuan yang belum berkembang yaitu mengkombinasikan 3 kata sehingga yang diucapkan ED kurang dimengerti, menggunakan bentuk jamak, analogi berlawanan, mengetahui 2 kata sifat, mendefinisikan kata-kata dan mengetahui kegunaan benda.

Berdasarkan hasil wawancara dan observasi, ditemukan permasalahan yaitu ED mengalami kesulitan dalam berbahasa ekspresif pada usianya 4 tahun saat ini serta ED masih mengalami kesulitan untuk mengekspesikan keinginan, kesulitan menjawab pertanyaan dan hanya dapat mengkombinasikan satu sampai dua kata. Berdasarkan penjelasan tersebut, maka target behavior dalam penelitian ini adalah kemampuan ED dalam memproduksi kombinasi tiga kata saat mengekspresikan keinginan seperti mengucapkan "saya mau (nama aktivitas/benda yang diinginkan)".

Pada tahap baseline 1 (A-1), target behavior (perilaku sasaran) yang telah ditentukan tidak muncul atau 0 kejadian di setiap sesi yaitu sesi pertama, sesi kedua dan ketiga. Berdasarkan pengamatan pelaksanaan baseline 1, pada saat mengekspresikan keinginannya ED cenderung menggunakan bahasa tubuh atau hanya mengucapkan satu sampai dua kata sehingga target behavior tidak muncul selama sesi baseline 1. Secara visual gambaran bahasa ekspresif tahap baseline 1 dapat digambarkan melalui grafik 1 .

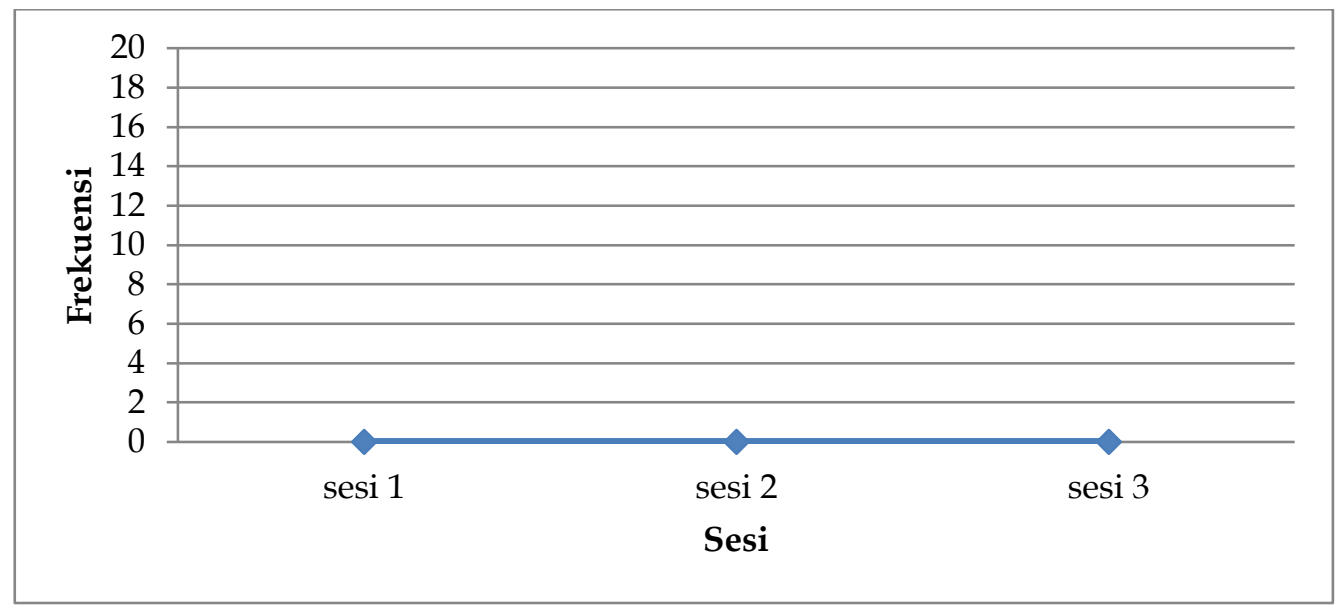

Grafik 1 Gambaran Bahasa Ekspresif Sebelum Intervensi1

Berdasarkan grafik 1, dapat dijelaskan bahwa pada tahap baseline 1 ini, pengamatan dilakukan sebanyak tiga sesi. Estimasi kecenderungan arah pada penelitian ini yaitu mendatar, yang berarti tidak terjadinya perubahan pada setiap sesi. Peneliti menghentikan pengamatan pada sesi ketiga karena data yang diperoleh stabil dari pengamatan sesi pertama sampai ketiga dan melanjutkan dengan tahap intervensi.

Tahap intervensi dilakukan sebanyak 8 sesi yaitu dengan pemberian metode Milleu Teaching. Pada tahap ini, frekuensi target behavior yaitu bahasa ekspresif mengalami peningkatan dalam setiap sesinya. Pada sesi 1 intervensi frekuensi target 
behavior mengalami peningkatan dibandingkan dengan sesi terakhir pada fase baseline 1 (A-1) yaitu 11, pada sesi berikutnya juga mengalami peningkatan namun pada sesi 3 dan 4 mengalami penurunan hingga mencapai skor frekuensi yaitu 10. Penurunan ini terjadi karena saat intervensi berlangsung ED lebih fokus terhadap satu permainan atau aktivitas saja. Pada sesi ke 5 mulai mengalami kenaikan sampai dengan sesi ke 8 yaitu mengalami peningkatan hingga 15,5. Hal ini dikarenakan pada sesi ke 5 adanya penambahan aktivitas permainan yang diberikan kepada ED. Gambaran bahasa ekspresif pada tahap intervensi dapat dilihat pada grafik 2 .

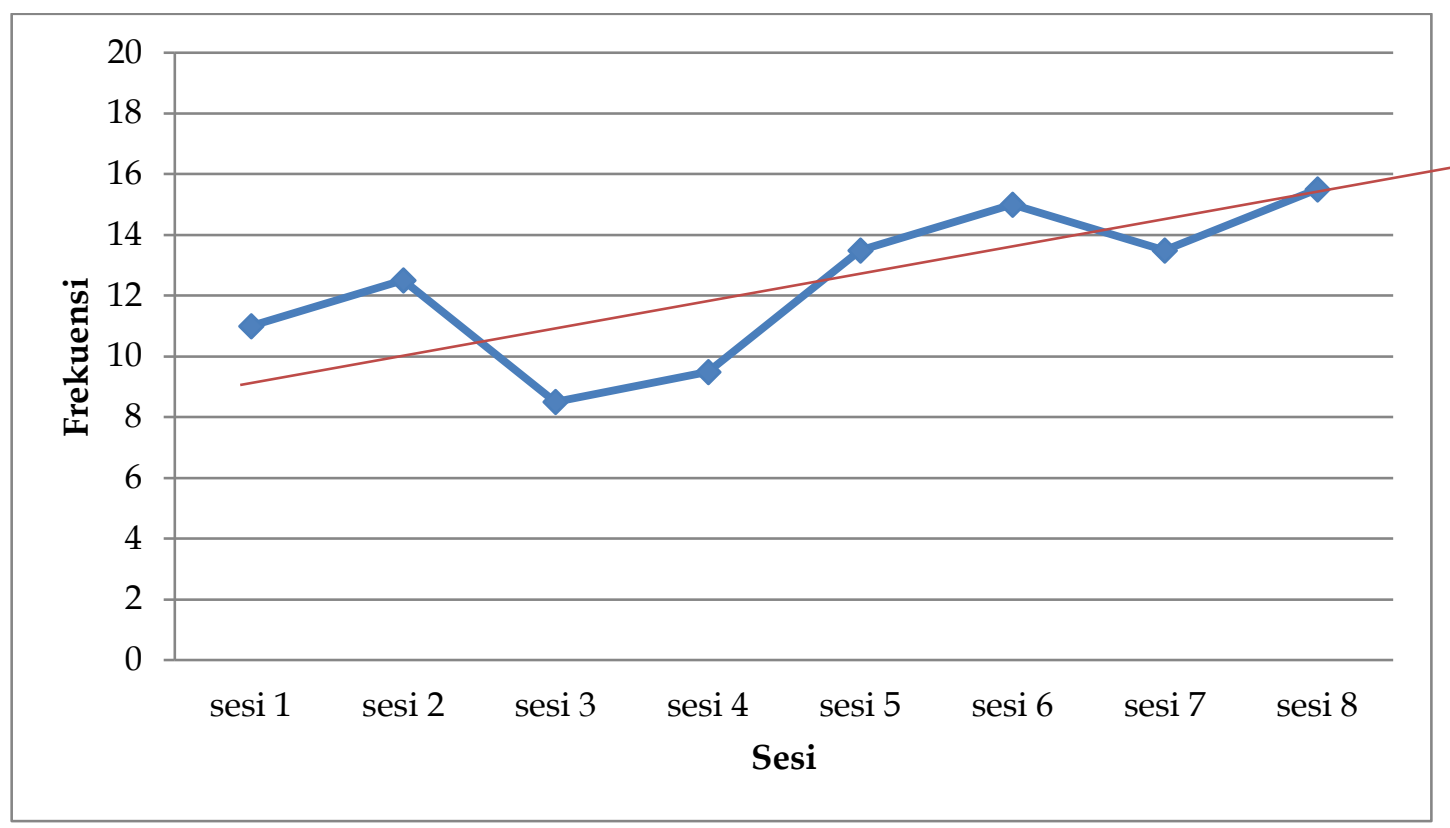

Grafik 2 Gambaran Bahasa Ekspresif pada Tahap Intervensi

Pada grafik 2 menunjukkan bahwa target behavior yaitu bahasa ekspresif memiliki estimasi kecenderungan arah meningkat yang berarti adanya peningkatan frekuensi dari sesi pertama sampai dengan sesi kedelapan. Kecenderungan stabilitas pada tahap intervensi adalah variabel, dengan persentase sebesar $37,5 \%$, artinya pada fase ini rentang data cenderung besar atau memiliki tingkat variasi yang tinggi. Pada tahap intervensi, level perubahannya adalah $+4,5$ yang menunjukkan bahwa adanya perubahan yang membaik.

Tahap berikutnya yaitu baseline 2. Pada tahap ini dilakukan pengamatan terhadap target behavior setelah diberikannya intervensi yaitu dengan pemberian metode milieu teaching. Frekuensi tertinggi yang diperoleh ED pada fase baseline 2 (A-2) adalah 7,5 dan frekuensi terendah adalah 6. Pada sesi 1 intervensi kemampuan bahasa ekspresif subjek dalam meminta hal yang diinginkan mengalami penurunan dari sesi terakhir pada tahap intervensi yaitu 6,5. Namun apabila dibandingkan dengan tahap baseline 1 (A-1) target perilaku mengalami peningkatan dari skor 0 menjadi 6,5. Pada sesi baseline 2 (A-2) berikutnya juga mengalami peningkatan sampai dengan sesi ke 3 atau sesi 
baseline 2 (A-2) terakhir yaitu peningkatan mencapai skor 7,5. Gambaran bahasa ekspresif pada tahap baseline 2 (A-2) dapat dilihat pada grafik 3.

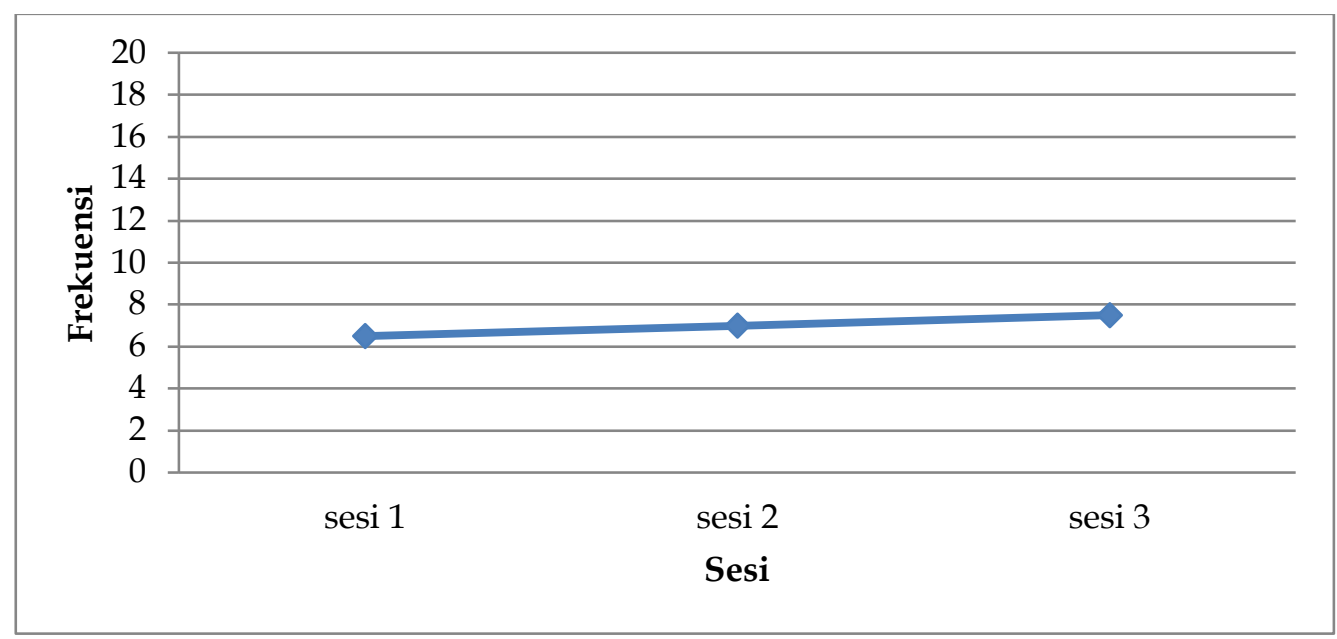

Grafik 3 Gambaran Bahasa Ekspresif Setelah Intervensi

Pada grafik 3 menunjukkan bahwa target behavior yaitu bahasa ekspresif pada tahap baseline 2 (A-2) memiliki estimasi kecenderungan arah meningkat yang berarti adanya peningkatan frekuensi dari sesi pertama sampai dengan sesi ketiga. Kecenderungan stabilitas pada tahap tahap baseline 2 (A-2) adalah stabil, dengan persentase sebesar $100 \%$ artinya pada fase ini rentang data cenderung kecil atau memiliki tingkat variasi yang rendah. Pada tahap baseline 2 (A-2), level perubahannya adalah $+4,5$ yang menunjukkan bahwa adanya perubahan yang membaik.

Setelah dilakukannya analisis dalam kondisi, langkah selanjutnya yang dilakukan yaitu analisis antar kondisi. Tujuan dilakukannya analisis antar kondisi yaitu melihat perubahan yang terjadi pada tahap baseline 1 (A-1), tahap intervensi dan tahap baseline 2 (A-2). Hal yang pertama dilakukan dalam menganalisis antar kondisi adalah memasukkan kode kondisi, yaitu kondisi baseline A-1, kondisi intervensi dan kondisi baseline A-2. Pada data, variabel yang diubah pada kondisi baseline (A-1) ke intervensi (B) adalah 1. Dengan demikian pada format atau tabel 1 akan terlihat seperti berikut ini.

Tabel 1. Data jumlah variabel diubah

\begin{tabular}{ccc}
\hline $\begin{array}{c}\text { Perbandingan } \\
\text { Kondisi }\end{array}$ & B/A-1 & A-2/B \\
\hline $\begin{array}{c}\text { Jumlah variabel } \\
\text { yang diubah }\end{array}$ & 1 & 1 \\
\hline
\end{tabular}

Hal kedua yang dilakukan yaitu dengan menentukan perubahan kecenderungan arah yang ditentukan dengan cara mengambil data pada analisis dalam kondisi di atas, hal ini dilakukan untuk melihat perubahan target behavior. Perubahan kecenderungan arah dapat terlihat jelas pada tabel 2. 
Tabel 2. Data kecenderungan arah

\begin{tabular}{ccc}
\hline $\begin{array}{c}\text { Perbandingan } \\
\text { Kondisi }\end{array}$ & $\mathbf{B} / \mathbf{A}-1$ & A-2/B \\
\hline $\begin{array}{c}\text { Perubahan } \\
\text { kecenderungan } \\
\text { arah }\end{array}$ & $>(+)$ \\
\hline
\end{tabular}

Kecenderungan arah perubahan yang terjadi pada target behavior yaitu bahasa ekspresif yang diteliti menjelaskan bahwa perubahan kecenderungan arah pada fase intervensi (B) dan baseline (A-1) cenderung meningkat (+). Sedangkan, kecenderungan arah perubahan yang terjadi pada fase baseline (A-2) dengan fase intervensi (B) juga cenderung meningkat $(+)$.

Langkah berikutnya dalam analisis antar kondisi yaitu menentukan perubahan level dapat dilakukan dengan menentukan data poin sesi terakhir kondisi baseline (A-1) dan sesi pertama pada intervensi (B), kemudian menghitung selisih dan tandai (=) bila naik, dan (=) tidak ada perubahan dan (-) bila turun, untuk lebih jelasnya perubahan level dijelaskan pada tabel 3.

Tabel 3. Data perubahan level

\begin{tabular}{ccc}
\hline Kondisi & B/A-1 & A-2/B \\
\hline Perbandingan & $11-0$ & $7-15,5$ \\
kondisi & +11 & $-8,5$
\end{tabular}

Berdasarkan data tabel 3 dapat disimpulkan bahwa perubahan level dari intervensi ke baseline (A-1) mengalami peningkatan. Kemudian dibandingkan antara baseline (A2) dengan intervensi (B) mengalami penurunan, akan tetapi bila dibandingkan dengan baseline (A-1) dengan fase baseline (A-2) anak mengalami peningkatan.

Langkah terakhir yang dilakukan dalam analisis antar kondisi yaitu menentukan data overlap yang berasal dari kesamaan data baseline 2 (A-2) dan intervensi dilihat dari acuan batas atas dan batas bawah intervensi tersebut, berikut data overlap A-2/B disajikan dalam grafik 4. 


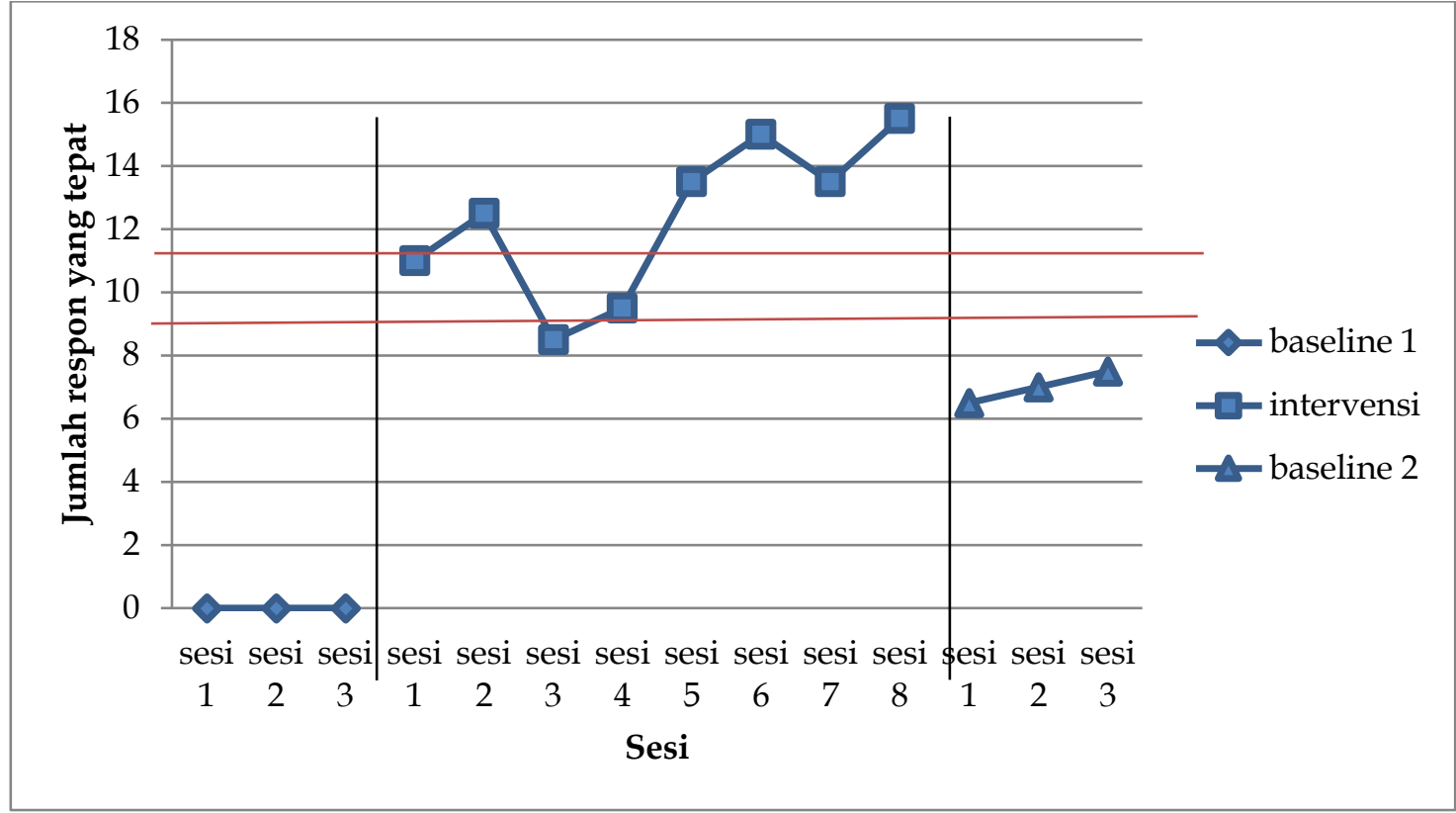

Grafik 4. Data Overlap A-2 dan B

Berdasarkan grafik 4 dapat terlihat bahwa tidak terdapat skor baseline A-2 yang termasuk ke dalam skor batas atas dan batas bawah fase intervensi (B), data overlap A2/B dalam penelitian dapat disederhanakan dalam bentuk tabel 4.

Tabel 4. Data persentase overlap

\begin{tabular}{ccc}
\hline $\begin{array}{c}\text { Perbandingan } \\
\text { kondisi }\end{array}$ & B/A-1 & A-2/B \\
\hline Persentase overlap & $(0: 8 \times 100)$ & $(0: 3 \times 100)$ \\
& $(0 \%)$ & $(0 \%)$ \\
\hline
\end{tabular}

Berdasarkan data tabel 4 dapat disimpulkan bahwa adanya pengaruh intervensi karena semakin kecil persentase overlap maka semakin baik pengaruh intervensi terhadap target perilaku. Dengan demikian dapat ditafsirkan bahwa kemampuan bahasa ekspresif anak mengalami perubahan yang meningkat melalui penerapan strategi milieu teaching.

\section{KESIMPULAN DAN SARAN}

Berdasarkan hasil penelitian dan pembahasan yang telah diuraikan maka dapat disimpulkan bahwa terdapat peningkatan kemampuan bahasa ekspresif anak yang mengalami keterlambatan bahasa melalui strategi milieu teaching, hal ini terlihat dari meningkatnya frekuensi target behavior yang telah ditentukan yaitu anak mengucapkan kalimat yang terdiri dari tiga kata untuk meminta mainan atau aktivitas yang diinginkan dari kondisi baseline 1 (A-1) dan dibandingkan dengan kondisi saat intervensi (B) dan kondisi baseline 2 (A-2). 
Saran untuk penelitian selanjutnya yaitu dapat melibatkan orangtua yang memiliki anak dengan keterlambatan bahasa sebagai partisipan penelitian, yang dimulai dengan pemberian pelatihan kepada orangtua dan selanjutnya orangtua dapat menerapkan strategi intervensi. Saran penelitian ini berdasarkan dari keterbatasan selama pelaksanaan penelitian.

Peneliti juga memberikan saran bagi orangtua dan guru subjek dalam mambantu anak untuk meningkatkan bahasa ekspresif yaitu dengan memperluas kata yang diucapkan oleh anak seperti apabila anak hanya mengucapkan satu kata, orangtua dan guru dapat merespon ucapan tersebut dengan menambahkan kata dan kalimat yang lengkap sehingga anak memiliki kosakata baru dan bantulah anak untuk mengucapkannya kembali. Orangtua maupun guru juga dengan segera memperbaiki dan mengoreksi ucapan kata anak yang salah. Orangtua dan guru juga tidak membiarkan anak hanya menggunakan bahasa tubuh yaitu salah satunya dengan menunjuk ketika anak menginginkan sesuatu namun memberikan kesempatan bagi anak untuk mengucapkan kata dengan tata bahasa yang lengkap.

\section{DAFTAR PUSTAKA}

Friend, M. (2011). Special education: contemporary perspectives for school professionals ( $3^{\text {rd }}$ ed.). New Jersey, NJ: Pearson Education.

Gast, D. L. (2010). Single subject research methodology in behavioral sciences. New York, NY: Routledge.

Heward, W. L. (2012). Exceptional children: An introduction to special education $\left(10^{\text {th }}\right.$ ed.). New Jersey, NJ: Pearson Education.

Kaiser, A. P., Hancock, T. B., \& Nietfeld, J. P. (2010). The effects of parentimplemented enhanced milieu teaching on the social communication of children who have autism. Journal of Early Education and Development, 4, 423-446. Retrieved from http://dx.doi.org/10.1207/s15566935eed1104_4.

Kaiser, A. P., Scherer, N. J., Frey, J. R., \& Roberts, M.Y. (2017). The effects of enhanced milieu teaching with phonological emphasis on the speech and language skills of young children with cleft palate: a pilot study. American Journal of Speech Language Pathology, 26, 806-818. Retrieved from https://doi.org/10.1044/2016_AJSLP-16-0008.

Kaiser, A. P., \& Trent, J. A. (2007). Communication intervention for young children with disabilities: Naturalistic approaches to promoting development. Handbook of developmental disabilities. New York, NY: Guilford Press.

Kring, M. A., Johnson, S. L., Davidson, G. C., \& Neale, J. M. (2010). Abnormal psychology (11 ${ }^{\text {th }}$ ed.). Hoboken, NJ: John Wiley \& Sons. 


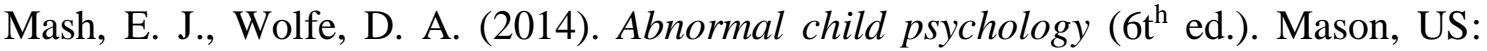
Cengage Learning.

Morrison, G, S. (2008). Fundamentals of early childhood education ( $7^{\text {th }}$ ed.). New Jersey, NJ: Pearson Education.

Papalia, D. E., Olds, S. W., Feldman, R. D. (2004). Human development (10 ${ }^{\text {th }}$ ed.). New York, NY: McGraw Hill.

Roberts, M. Y., Kaiser, A. P. (2012). Assessing the effects of a parent-implemented language intervention for children with language impairments using empirical benchmarks: A pilot study. Journal of Speech, Language, and Hearing Research, 55, 1655-1670. doi: 10.1044/1092-4388(2012/11-0236).

Santrock, J. W. (2007). Child Development (11 ${ }^{\text {th }}$ ed.). New York, NY: McGraw-Hill.

Slavin, R, E. (2009). Educational psychology: Theory and practice (9 $9^{\text {th }}$ ed.). New Jersey, NJ: Pearson Education.

Stock, C. D., \& Fisher, P. A. (2006). Language delay among foster children implications for policy and practice. Children Welfare, 85, 445-461. doi: 10.1.1.595.8621\&rep=rep1\&type=pdf. 